\title{
EFFECTS OF FLOOD SEASONALITY AND FREQUENCY ON NORTHERN PINTAILS AND OTHER BREEDING DUCKS IN MANAGED PRAIRIE WETLANDS
}

\author{
Stephen A. Asamoah 1,3 , Edward W. Bork ${ }^{1,4}$, and Jonathan E. Thompson²
}

\begin{abstract}
Anthropogenic flooding to create wetlands is a management option intended to compensate for historical loss of natural wetlands in the Dry Mixedgrass Prairie of western Canada. It may help moderate or reverse declines in density of breeding Northern Pintails (Anas acuta L.) and other waterfowl. Little information exists, however, on breeding waterfowl use of created wetlands flooded at different seasons and frequencies. This study assessed the effects of 2 flooding seasons (fall and spring) on abundance of breeding Northern Pintails and other ducks within newly created wetlands. Additionally, we compared breeding waterfowl use of sites with spring and fall flooding by using 2 treatments $(1$ year vs. 2 years of flood cessation) intended to alter vegetation composition and density (measured as visual obstruction) on older wetlands currently dominated by cattail (Typha latifolia L.). Vegetation density was assessed across the landscape in all treatments. While recently initiated fall and spring flooding each increased breeding duck densities compared to naturally flooded wetlands, spring flooding led to a greater density of Northern Pintails and other ducks in 1 of 3 years. Within established wetlands, 2 years of flood cessation led to a marked decline in duck abundance, while removal of flooding for one year led to the greatest duck abundance, even compared to wetlands with sustained fall flooding. Finally, vegetation density (i.e., visual obstruction) varied by flooding treatment and year of sampling, and was an important predictor of use of created wetlands by both Northern Pintails and other duck species. Collectively, these results indicate that duck use of managed wetlands in the Dry Mixedgrass Prairie of western Canada can be maximized with carefully planned flooding treatments that include spring flooding in newly created wetlands and intermittent flooding in established wetlands.
\end{abstract}

RESUMEN.-Una de las opciones en la gestión para compensar la pérdida histórica de humedales naturales en la pradera seca de pastos mixtos del oeste de Canadá es la inundación antropogénica para crear humedales; esto podría contribuir a la moderación o reversión de los descensos en la densidad del ánade rabudo (Anas acuta L.) y otras aves acuáticas en su tiempo de reproducción. Existe poca información, sin embargo, sobre el uso por aves acuáticas de humedales artificiales inundados en distintas temporadas y con distintas frecuencias. Este estudio evaluó los efectos de 2 temporadas de inundación (otoño vs. primavera) en la abundancia del ánade rabudo y otros patos durante el mes de mayo en humedales recién creados. Además, comparamos el uso por aves acuáticas de sitios con inundaciones en la primavera y el otoño con 2 tratamientos ( 1 vs. 2 años de cese de inundación) con la intención de cambiar la composición y densidad de la vegetación (medida por la obstrucción visual) en humedales más antiguos donde actualmente prevalece la enea (Typha latifolia L.). Se evaluó la densidad de vegetación en todo el paisaje con todos los tratamientos. Aunque las recién iniciadas inundaciones de otoño y primavera incrementaron las densidades de patos en reproducción, comparado con humedales inundados naturalmente, la inundación primaveral ocasionó una densidad mayor de ánades rabudos y otros patos en 1 de los 3 años. En humedales establecidos, el cese de inundación por 2 años causó una marcada disminución en la abundancia de patos, mientras que el cese de inundación por un año ocasionó una abundancia mayor de patos, incluso con relación a los humedales con inundación otoñal constante. Por último, la densidad de vegetación (i.e. la obstrucción visual) varió de acuerdo con el tratamiento de inundación y al año de muestreo, y fue un importante predictor del uso de humedales artificiales tanto por el ánade rabudo como por otras especies de patos. Colectivamente, estos resultados indican que se puede maximizar el uso por patos de humedales controlados en la pradera seca de pastos mixtos del oeste de Canadá mediante tratamientos de inundación cuidadosamente planeados, que incluyan inundación primaveral en humedales recién creados e inundación intermitente de humedales establecidos.

The Prairie Pothole Region of Canada provides important breeding habitat for many waterfowl species in North America (Keith 1961, Krapu 2000). However, climatic and anthropogenic changes, particularly those that have contributed to wetland loss, have led to popula- tion declines in some species of waterfowl (Millar 1989, Podruzny et al. 2002), most notably the Northern Pintail (Anas acuta; hereafter referred to as pintail), which remains well below its continental population goal established by the North American Waterfowl Management Plan

\footnotetext{
${ }^{1}$ Faculty of Aoricultural, Life and Environmental Sciences, University of Alberta, Edmonton, Alberta Canada T6G 2P5.

${ }^{2}$ Ducks Unlimited Canada, \#200, 10720 - 178 St. NW, Edmonton, Alberta, Canada T5S 1J3.

${ }^{3}$ Present address: Department of Fisheries and Oceans, 200 Kent Street, Ottawa, Ontario, Canada K1A 0E6.

${ }^{4}$ Corresponding author. E-mail: edward.bork@ualberta.ca
} 
(NAWMP 2004). Historically, most of North America's pintails nested in the prairie grasslands of western Canada, which are interspersed with numerous temporary, seasonal, and semipermanent wetlands (Kaminski and Weller 1992, Austin and Miller 1995). However, like most of the Prairie Pothole Region, these southern grasslands have experienced high rates of native grassland and wetland loss from intensified agriculture, which in turn negatively affects pintail and other waterfowl populations (Boyd 1985, Millar 1989, Nudds and Clark 1993, Miller and Duncan 1999, Podruzny et al. 2002).

To moderate the effects of frequent drought and wetland loss throughout the Dry Mixedgrass Prairie of Alberta, wetlands have been created to enhance waterfowl production (Keith 1961, Sankowski et al. 1987). These wetlands are maintained by supplemental flooding to augment available moisture in natural wet meadows. Created wetlands were originally flooded 3 times a year between May and August to maintain water levels, which initially resulted in greater spikerush (Eleocharis palustris) production, as well as increased overall use and productivity of local waterfowl (Sankowski et al. 1987). Spikerush is typical of the temporary and seasonal wetlands preferred by pintails in the Dry Mixedgrass Prairie, and seeds of this plant are consumed by both adult and juvenile dabbling ducks (Keith 1961). However, a shift from short-term flooding under natural conditions to more prolonged flooding in managed wetlands has altered vegetation composition and structure by gradually replacing spikerush with cattail (Typha latifolia). In recognition of this problem, water management was altered within these basins in 2000, after which basins were flooded once annually in August or September (i.e., fall) to reduce wetland permanence with the intent of restoring low-structured, open wetland habitats preferred by pintails. Fall flooding also is compatible with water demand within the irrigation districts because fall coincides with the period when water demand for crop production is low.

To date, little information exists on the specific effect of flood seasonality and duration on use of managed wetlands by breeding pintails and other waterfowl, nor is there certainty about the vegetation communities and structure produced by these management options. This information is necessary to produce those plant communities desirable for waterfowl in newly created and established wetlands. To explore the effect of wetland flooding regimes on waterfowl and their habitats in the Dry Mixedgrass Prairie, we conducted annual breeding waterfowl surveys on a series of created wetlands over a 3-year period, including older established wetlands and newly flooded wetlands.

Within newly created wetlands, we hypothesized that the density of pintails and other ducks would not differ between wetlands receiving natural flooding (i.e., snowmelt and rainfall) and either supplemental fall or spring flooding. Within established wetlands, we hypothesized that planned changes in the season and frequency of flooding intended to alter vegetation composition would not alter the abundance of pintails or other ducks.

\section{Methods}

\section{Study Area}

We examined newly established wetlands within the Contra-Costa complex and established wetlands at the Kitsim complex, both in the Dry Mixedgrass Prairie near Brooks, Alberta, Canada $\left(50^{\circ} 33^{\prime} \mathrm{N}, 111^{\circ} 51^{\prime} \mathrm{W}\right)$. These wetlands were developed in the Eastern Irrigation District (EID) to provide improved waterfowl breeding habitat and grazing opportunities for cattle. While much of the EID has been converted to row crop agriculture, large tracts of native prairie remain and are used for cattle grazing, wildlife conservation, recreational activities, and energy extraction. Management of these wetlands includes use of gravity-fed irrigation canals that transport water from holding reservoirs to maintain created wetland complexes. Strategically placed flood control structures enable regulation of the timing (i.e., season) and amount (i.e., depth) of flooding. In addition to supplemental flooding, wetland moisture cycles are affected by annual recharge from spring snowmelt and growing season rainfall, as well as year-round losses due to evapotranspiration. Long-term (30-year) average annual precipitation (1971-2000) at Brooks is $348 \mathrm{~mm}$. Annual precipitation values prior to and during the study were $171 \mathrm{~mm}$ in 2001 (49\% of normal), $345 \mathrm{~mm}$ in 2002 (99\%), $267 \mathrm{~mm}$ in 2003 (77\%), $299 \mathrm{~mm}$ in 2004 (86\%), and $537 \mathrm{~mm}$ in 2005 (154\%; Environment Canada unpublished data).

A total of 8 and 16 wetlands were studied at Contra-Costa and Kitsim, respectively, from 
TABLE 1. Schedule of supplemental flooding treatments implemented on study wetlands at Contra-Costa to examine aspects of new wetland development in the Dry Mixedgrass Prairie of southeastern Alberta, Canada.

\begin{tabular}{|c|c|c|c|c|c|c|c|c|}
\hline \multirow{2}{*}{$\begin{array}{l}\text { Wetland } \\
\text { basin }\end{array}$} & \multirow[b]{2}{*}{ Size (ha) } & \multirow{2}{*}{$\begin{array}{l}\text { Flooding } \\
\text { treatment }^{\mathrm{a}}\end{array}$} & \multirow{2}{*}{$\begin{array}{c}2002 \\
\text { Fall }\end{array}$} & \multicolumn{2}{|c|}{2003} & \multicolumn{2}{|c|}{2004} & \multirow{2}{*}{$\begin{array}{c}2005 \\
\text { Spring }\end{array}$} \\
\hline & & & & Spring & Fall & Spring & Fall & \\
\hline Con-A & 4.2 & $\mathrm{FF}$ & flood & & flood & & flood & \\
\hline Con-B & 3.7 & SF & & flood & & flood & & flood \\
\hline Con-C & 3.1 & SF & & flood & & flood & & flood \\
\hline Con-D & 7.0 & $\mathrm{FF}$ & flood & & flood & & flood & \\
\hline Con-E & 7.3 & $\mathrm{FF}$ & flood & & flood & & flood & \\
\hline Con-F & 7.5 & FF & flood & & flood & & flood & \\
\hline Con-G & 2.5 & $\mathrm{NF}$ & $\mathrm{n} / \mathrm{a}$ & $\mathrm{n} / \mathrm{a}$ & $\mathrm{n} / \mathrm{a}$ & $\mathrm{n} / \mathrm{a}$ & $\mathrm{n} / \mathrm{a}$ & $\mathrm{n} / \mathrm{a}$ \\
\hline Con-H & 2.1 & $\mathrm{NF}$ & $\mathrm{n} / \mathrm{a}$ & $\mathrm{n} / \mathrm{a}$ & $\mathrm{n} / \mathrm{a}$ & $\mathrm{n} / \mathrm{a}$ & $\mathrm{n} / \mathrm{a}$ & $\mathrm{n} / \mathrm{a}$ \\
\hline
\end{tabular}

$\mathrm{a} F \mathrm{~F}=$ fall flooding, $\mathrm{SF}=$ spring flooding, and $\mathrm{NF}=$ natural (no artificial) flooding.

TABLE 2. Schedule of supplemental flooding treatments implemented on well-established cattail-dominated wetlands at Kitsim in the Dry Mixedgrass Prairie of southeastern Alberta, Canada. The 4 wetlands selected for the 2 YNF treatment were last flooded in fall 2001, which was considered the initial pretreatment flooding date for these sites. Pretreatment flooding for all remaining wetlands was implemented in fall 2002.

\begin{tabular}{|c|c|c|c|c|c|c|c|c|}
\hline \multicolumn{2}{|c|}{ Wetland basin } & \multirow[b]{2}{*}{$\begin{array}{l}\text { Flooding } \\
\text { treatment }\end{array}$} & \multirow{2}{*}{$\begin{array}{c}2002 \\
\text { Fall }\end{array}$} & \multicolumn{2}{|c|}{2003} & \multicolumn{2}{|c|}{2004} & \multirow{2}{*}{$\begin{array}{r}2005 \\
\text { Spring }\end{array}$} \\
\hline $\begin{array}{l}\text { Study } \\
\text { label }\end{array}$ & Size (ha) & & & Spring & Fall & Spring & Fall & \\
\hline Kit-A & 9.4 & $1 \mathrm{YNF}$ & flood & & no flood & & flood & \\
\hline Kit-B & 9.1 & $1 \mathrm{YNF}$ & flood & & no flood & & flood & \\
\hline Kit-C & 16.6 & $2 \mathrm{YNF}$ & no flood & & no flood & & flood & \\
\hline Kit-D & 6.3 & SF & flood & & no flood & flood & & flood \\
\hline Kit-E & 14.9 & $\mathrm{FF}$ & flood & & flood & & flood & \\
\hline Kit-F & 14.9 & $\mathrm{FF}$ & flood & & flood & & flood & \\
\hline Kit-G & 5.0 & $1 Y N F$ & flood & & no flood & & flood & \\
\hline Kit-H & 3.3 & $1 \mathrm{YNF}$ & flood & & no flood & & flood & \\
\hline Kit-I & 9.6 & $\mathrm{SF}$ & flood & & no flood & flood & & flood \\
\hline Kit-J & 9.2 & $\mathrm{SF}$ & flood & & no flood & flood & & flood \\
\hline Kit-K & 13.6 & $2 \mathrm{YNF}$ & no flood & & no flood & & flood & \\
\hline Kit-L & 12.1 & $\mathrm{SF}$ & flood & & no flood & flood & & flood \\
\hline Kit-M & 13.6 & $2 \mathrm{YNF}$ & no flood & & no flood & & flood & \\
\hline Kit-N & 14.2 & $\mathrm{FF}$ & flood & & flood & & flood & \\
\hline Kit-O & 14.2 & $\mathrm{FF}$ & flood & & flood & & flood & \\
\hline Kit-P & 7.8 & $2 \mathrm{YNF}$ & no flood & & no flood & & flood & \\
\hline
\end{tabular}

2002 to 2005. Created wetlands at ContraCosta were relatively new $(<2$ years old) and comprised minimally altered meadow communities dominated by foxtail barley (Hordeum jubatum L.), western dock (Rumex occidentalis S. Wats.), and spikerush, while those at Kitsim were heavily dominated by cattail following many years ( $>20$ years) of flooding.

Experimental Design and Flooding Treatments

A completely randomized design was used to assess the effects of different flooding treatments on the density of pintails and other ducks. Flooding at Contra-Costa included annual supplemental flooding during fall (FF) or spring (SF) and a control (i.e., natural flooding only; Table 1).
There were 4 replicates of FF wetlands, and 2 each of SF and naturally flooded treatments. At Kitsim, flooding treatments included 4 replicates each of annual FF or SF from 2003 through 2005 , as well as 2 flood-cessation treatments (Table 2). The latter included the absence of FF for either one year ( $1 \mathrm{YNF}$ ) or 2 years $(2 \mathrm{YNF})$ to examine the influence of short-term wetland drying on habitat conditions and associated duck use. All wetlands at Kitsim were flooded in fall 2004 or spring 2005 to assess waterfowl responses to vegetation changes induced by the previous flooding regimes.

A split-plot design was used within each wetland to assess the effects of flooding on vegetation across the landscape. At Kitsim, the landscape 
was stratified into existing vegetation classes for sampling, including deep marsh (i.e., permanent water), wet meadow (extended SF), dry meadow (short-term SF) and upland (subirrigated) zones. However, in new wetlands at Contra-Costa, where vegetation was in the early stages of change following flooding, sampling was done at 4 standardized depths of flooding: deep flooding $(60 \mathrm{~cm})$, shallow flooding $(30 \mathrm{~cm})$, waterline $(0 \mathrm{~cm})$, and subirrigated upland $(-30 \mathrm{~cm})$ zones.

\section{Abundance of Breeding Northern Pintails and Other Ducks}

We determined indicated breeding duck density (IBDD) for pintails and other ducks at both Contra-Costa and Kitsim during the spring seasons of 2003, 2004, and 2005, using the analytical approach recommended for waterfowl surveys by the United States Fish and Wildlife Service (USFWS 1987). IBDD was assessed by surveying pintails and all other species of ducks encountered by using a direct ground-based waterfowl counting technique (Dzubin 1969). To account for temporal variation in the breeding chronology of waterfowl, 3 separate counts of each wetland were made annually_in early, mid-, and late May. The largest of the 3 counts for each species was used in calculating annual IBDD of both pintails and other ducks encountered for each wetland.

\section{Waterfowl Habitat Assessment}

Visual obstruction readings (VOR; Robel et al. 1970) were taken yearly at Contra-Costa and in 2002, 2004, and 2005 at Kitsim along permanent transects established within various topographic positions stratified across the landscape. VOR was not measured within the shallow and deep flooding zones at Contra-Costa, where recent flooding rendered such measurements unnecessary given the limited emergent vegetation found there. Similarly, VOR was not assessed in the deep marsh zone at Kitsim, where tall vegetation (T. latifolia) precluded VOR. Permanent transects $20 \mathrm{~m}$ in length were located using a laser level (Leica Wild LNA $30^{\mathrm{TM}}$ ) and a stratified random approach at each position, with the coordinates for each transect marked using GPS to facilitate relocation. The laser level ensured that transects remained at the same elevational contour (i.e., flood depth) within each topographic position of each wetland. VOR assessments were undertaken within twenty $0.25-\mathrm{m}^{2}$ quadrats systematically placed along each transect during peak biomass in June or July of each year. VOR was measured within each quadrat using a 1.5-m graduated (Robel) pole, a meter-rule, and a $4-\mathrm{m}$ rope in accordance with the technique developed by Robel et al. (1970) and modified by Higgins and Baker (1982) and Benkobi et al. (2000).

\section{Data Analyses}

Indicated breeding duck abundance (IBDA) of each duck species encountered, except Redhead (Aythya americana), Lesser Scaup (Aythya affinis), Ring-necked Duck (Aythya collaris), and Ruddy Duck (Oxyura jamaicensis), was calculated using the formula (Eq. 1) below for each wetland:

$$
\begin{aligned}
\text { IBDA }= & (2 \times \text { Pairs })+(2 \times \text { Lone Males }) \\
& +(2 \times \text { Flocked Males }<5) \\
& +(1 \times \text { Grouped Males and Females }>4)
\end{aligned}
$$

(Eq. 1).

The above equation was modified (Eq. 2) to facilitate calculation of IBDA of Redhead, Lesser Scaup, Ring-necked Duck, and Ruddy Duck (USFWS 1987), as these species can have sex ratios that are highly biased toward males:

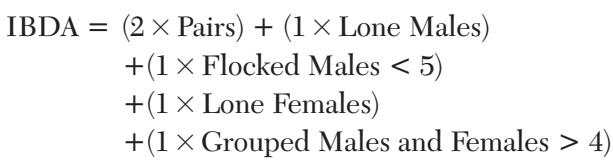

(Eq. 2).

Next, the greatest IBDA of each waterfowl species (excluding pintails) was identified, and these values were summed to determine overall abundance of other ducks on each wetland.

Data on IBDA and VOR from each location (Contra-Costa and Kitsim) were analyzed separately due to differences in age of wetlands and types of flooding treatments implemented. Furthermore, because wetlands were of variable size and given that size positively influences the likelihood of use by waterfowl (Stewart and Kantrud 1974, Savard et al. 1994), a conclusion supported by the present study (Asamoah 2008), all IBDA data were converted to IBDD for each wetland prior to analysis (Eq. 3):

$\mathrm{IBDD}=\mathrm{IBDA} /$ wetland size $(\mathrm{ha})$

(Eq. 3).

Statistical analysis of waterfowl data evaluated the effects of flooding treatment, census year, 
TABLE 3. Summary of the analysis for effects of flooding treatment, census year, and their interaction on indicated breeding duck density of Northern Pintails and other ducks at Contra-Costa and Kitsim during May 2003, 2004, and 2005. Bolded probability values were considered statistically significant.

\begin{tabular}{|c|c|c|c|c|c|c|}
\hline \multirow[b]{2}{*}{ Site } & \multirow[b]{2}{*}{ Source } & \multirow[b]{2}{*}{$\mathrm{df}$} & \multicolumn{2}{|c|}{ Northern Pintail } & \multicolumn{2}{|c|}{ Other ducks } \\
\hline & & & $F$ & $P>F$ & $F$ & $P>F$ \\
\hline \multirow[t]{3}{*}{ Contra-Costa } & Flooding treatment & 2 & 4.98 & 0.02 & 10.43 & $<0.01$ \\
\hline & Census year & 2 & 0.10 & 0.91 & 0.77 & 0.48 \\
\hline & Flooding $\times$ Year & 4 & 2.38 & 0.10 & 2.53 & 0.08 \\
\hline \multirow[t]{3}{*}{ Kitsim } & Flooding treatment & 3 & 4.47 & $<0.01$ & 5.54 & $<0.01$ \\
\hline & Census year & 2 & 5.19 & 0.01 & 1.16 & 0.32 \\
\hline & Flooding $\times$ Year & 6 & 2.07 & 0.08 & 0.12 & 0.99 \\
\hline
\end{tabular}

TABLE 4. Variation in indicated breeding duck density (IBDD) of Northern Pintails and other ducks in response to fall, spring, and natural flooding treatments at Contra-Costa from spring 2003 to 2005 . Within each year, flooding treatment means with different lowercase letters differ significantly $(P<0.05)$. Flooding treatment grand means with different uppercase letters differ significantly $(P<0.05)$.

\begin{tabular}{|c|c|c|c|c|c|}
\hline \multirow[b]{2}{*}{ Flooding treatment } & \multicolumn{3}{|c|}{ Census year } & \multirow[b]{2}{*}{ Mean (flooding) } & \multirow[b]{2}{*}{ SE } \\
\hline & 2003 & 2004 & 2005 & & \\
\hline \multicolumn{6}{|l|}{ Northern Pintail } \\
\hline Fall flooding & $2.8 \mathrm{a}$ & $1.9 \mathrm{ab}$ & $1.6 \mathrm{~b}$ & $2.1 \mathrm{~B}$ & 0.4 \\
\hline Spring flooding & $1.7 \mathrm{a}$ & $3.6 \mathrm{a}$ & $5.7 \mathrm{a}$ & $3.7 \mathrm{~A}$ & 0.6 \\
\hline Natural flooding & $1.8 \mathrm{a}$ & $0.1 \mathrm{~b}$ & $0 \mathrm{~b}$ & $0.9 \mathrm{C}$ & 0.6 \\
\hline \multicolumn{6}{|l|}{ Other ducks } \\
\hline Fall flooding & $15.1 \mathrm{a}$ & $10.5 \mathrm{~b}$ & $14.5 \mathrm{a}$ & $13.4 \mathrm{~A}$ & 1.5 \\
\hline Spring flooding & $7.8 \mathrm{ab}$ & $21.7 \mathrm{a}$ & $18.4 \mathrm{a}$ & $16.0 \mathrm{~A}$ & 2.2 \\
\hline Natural flooding & $4.3 \mathrm{~b}$ & $5.2 \mathrm{~b}$ & $0 \mathrm{~b}$ & $3.2 \mathrm{~B}$ & 2.2 \\
\hline
\end{tabular}

and flooding $\times$ census year interactions on the IBDD of pintails and other ducks. Analysis was done using Proc MIXED in SAS (SAS Institute, Inc. 2003), with replicate wetlands considered random. All analyses used LSmeans. Due to limited sample sizes, the main effects of flooding and interactions with year were deemed significant at $P<0.10$.

Statistical analysis of the VOR data used an ANCOVA for split-plot designs (Steele et al. 1997) in Proc MIXED in SAS (SAS Institute, Inc. 2003) to evaluate the effects of flooding across topographic positions at Contra-Costa and Kitsim. VOR data from 2002 were used as covariates in the analysis to control for initial variation in vegetation height and thereby isolate changes in VOR from 2002 to the time of measurement. Year was included as a fixed effect in the assessment of VOR from Contra-Costa, while VOR from Kitsim in 2004 and 2005 were assessed separately: these dates represented the end-of-treatment and post-reflooding periods, respectively. Multiple comparisons $(P<0.05)$ on all significant flooding treatment effects and interactions $(P<0.10)$ were conducted on LSmeans using Tukey's test, with emphasis on flooding effects or its interaction with position. Finally, regression was used to explore the empirical relationship between IBDD and measured VOR in wetlands experiencing variable flooding. Nonlinear models were considered where goodness-of-fit improved by $\geq 10 \%$.

\section{Results}

\section{Duck Responses at Contra-Costa}

The breeding densities of pintails and other ducks at Contra-Costa were affected by flooding treatment $(P \leq 0.02)$, as well as the flooding $\times$ year interaction $(P \leq 0.10$; Table 3$)$. While no differences in pintail breeding density existed among flooding treatments in 2003, greater pintail breeding density occurred in SF areas than in naturally flooded areas during 2004 (Table 4). In 2005, SF areas had markedly greater pintail breeding density than both FF and naturally flooded areas, with fall wetlands having intermediate pintail breeding density (Table 4).

The IBDD of other ducks also demonstrated substantial variation among years and flooding treatments. During 2003, FF wetlands had greater IBDD of other ducks compared to 


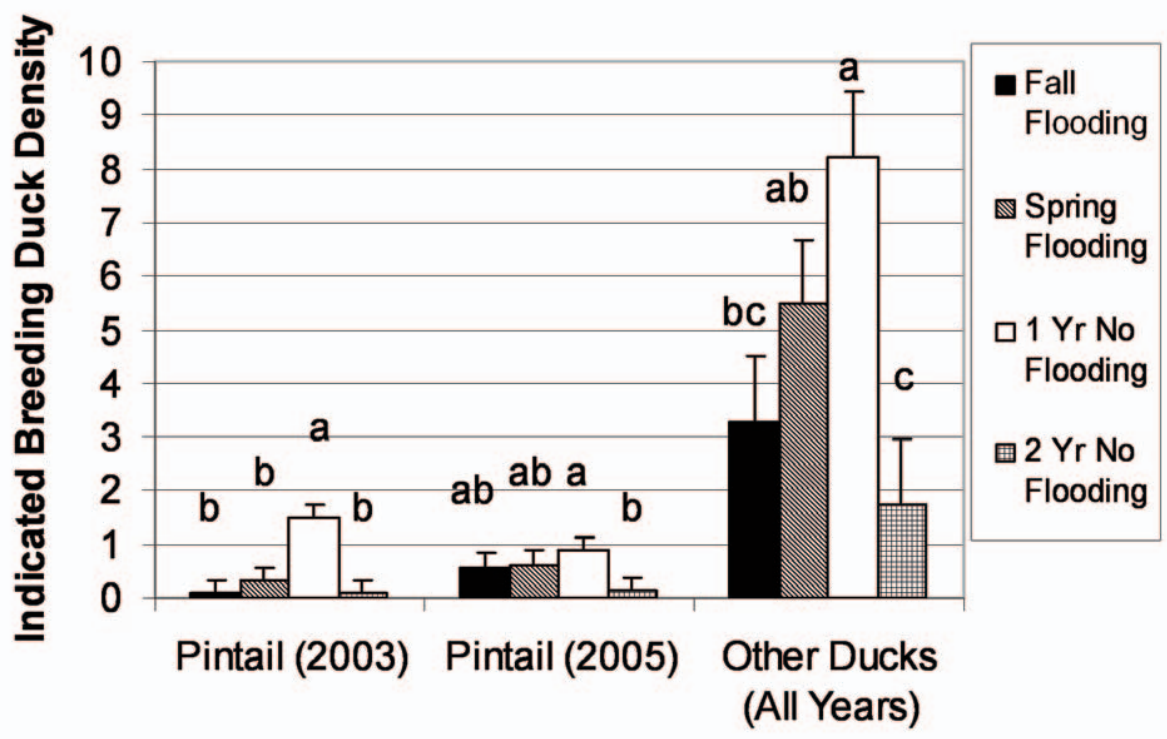

Fig. 1. Indicated breeding duck density of Northern Pintails and other ducks in response to supplemental flooding during fall $(\mathrm{FF})$ and spring $(\mathrm{SF})$, and 2 flood-cessation treatments (1 or 2 years no flooding) during waterfowl surveys at Kitsim between 2003 and 2005. Treatments with different letters within a grouping differ significantly, $P<0.05$.

natural wetlands, while SF wetlands did not differ from the others (Table 4). In 2004, however, SF areas had greater IBDD than both FF and naturally flooded areas, with IBDD values under $\mathrm{SF}$ regimes more than twice that of other flooding regimes (Table 4). During 2005, the IBDD of other ducks remained very low in naturally flooded wetlands, well below that of $\mathrm{SF}$ and FF areas (Table 4).

Overall, the proportion of total IBDD (i.e., pintail + other ducks) consisting of pintails within the flooding treatments at Contra-Costa was $13.5 \%$ on $\mathrm{FF}$ wetlands and $18.8 \%$ on SF wetlands, respectively. Although natural wetlands had the lowest absolute IBDD for both pintails and other ducks (Table 4), these wetlands had the greatest breeding density of pintails $(22.0 \%)$ relative to all waterfowl throughout the study.

\section{Duck Responses at Kitsim}

The IBDD of other ducks at Kitsim exhibited a response to flooding treatment only $(P<0.01)$, with no variation among years (Table 3$)$. Overall, wetlands exposed to 1YNF had greater IBDD of other ducks compared to those subject to either FF or 2 YNF treatments (Fig. 1). Although SF wetlands had an IBDD of other ducks similar to that of $1 \mathrm{YNF}$ wetlands, SF wetlands also had an IBDD of other ducks greater than that of 2YNF wetlands (Fig. 1).

The breeding density of pintails at Kitsim was affected by flooding treatment $(P<0.01)$, census year $(P=0.01)$, and a flooding $\times$ year interaction $(P=0.08$; Table 3$)$. During 2003, pintail breeding density was greater in $1 \mathrm{YNF}$ wetlands than in all others (Fig. 1). One year later, the breeding density of pintails remained low across all flooding treatments (IBDD values $\leq 0.10$ ), with no differences evident (data not shown). By 2005, however, 1YNF wetlands had a greater breeding density of pintails compared to $2 \mathrm{YNF}$ wetlands (Fig. 1).

Across all wetlands at Kitsim, the proportion of total IBDD (among all waterfowl) consisting of pintails remained low, ranging from $4.4 \%$ in the $2 \mathrm{YNF}$ to $8.8 \%$ in the $1 \mathrm{YNF}$. Values from $\mathrm{FF}$ and $\mathrm{SF}$ areas were intermediate at $6.3 \%$ and $6.0 \%$, respectively.

Relationship Between IBDD and Wetland Size

Although the breeding density of pintails at Contra-Costa appeared to increase with wetland size in all 3 years to a peak around 5 ha and wetland size explained between $19 \%$ and $64 \%$ of variance in pintail breeding density, these relationships remained insignificant $(P$ $>0.42$; Fig. 2). In contrast, the IBDD of 


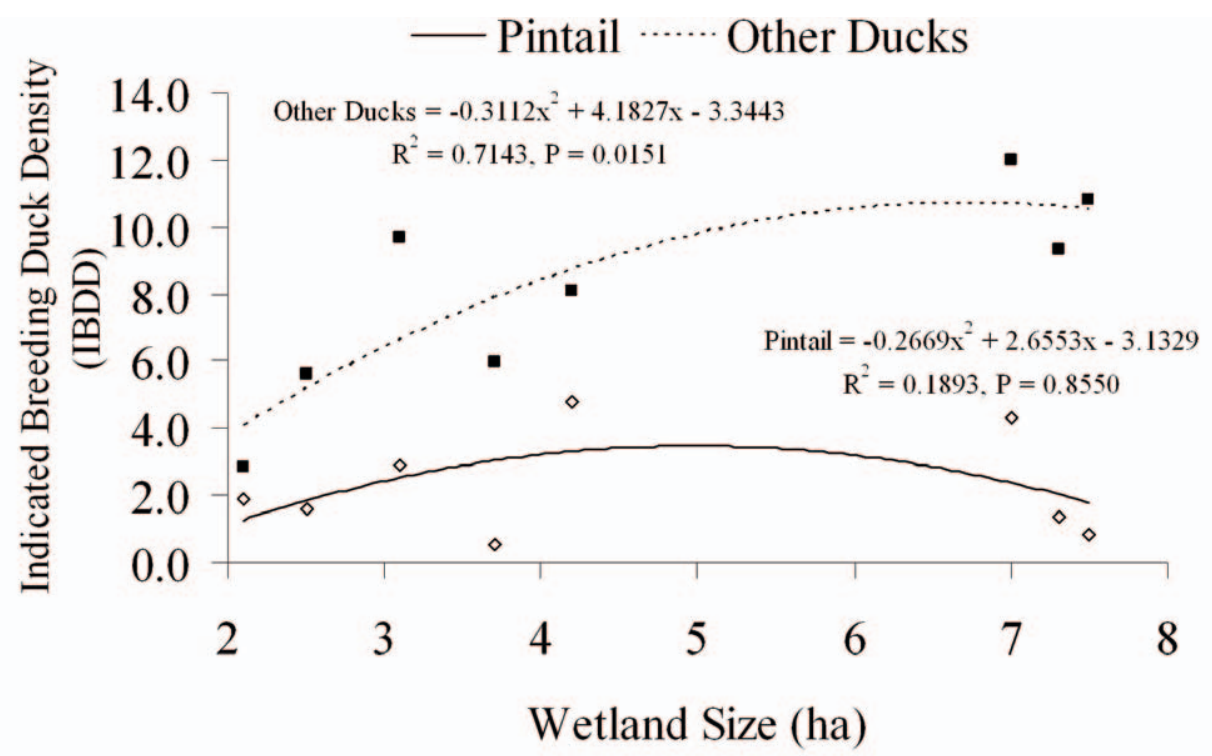

Fig. 2. Relationship between wetland size and indicated breeding duck density of Northern Pintails and other ducks at Contra-Costa during 2005.

other ducks increased sharply with wetland size $(P=0.02)$ but only during the first year of study in 2003 (Fig. 2). At Kitsim, the breeding density both of pintails and of other ducks showed no relationship with wetland size (e.g., $\mathrm{R}^{2}<0.01$ in 2005).

\section{Visual Obstruction Responses}

Flooding treatment alone did not affect VOR from 2002 on at Contra-Costa $(P>0.05)$. However, VOR varied spatially across topographic positions and temporally among sampling years $(P<0.0001)$. Additionally, VOR was affected by a flooding treatment $\times$ topographic position interaction $(P<0.0001)$, with further interactions of sampling year $\times$ flooding treatment $(P<$ $0.0001)$ and sampling year $\times$ topographic position $(P<0.0001)$.

FF wetlands at Contra-Costa generally had the greatest VOR $(3.2 \pm 0.02 \mathrm{dm})$ in adjacent uplands, while SF wetlands had the greatest VOR $(2.0 \pm 0.02 \mathrm{dm})$ in waterline zones. The lowest VOR $(1.2 \pm 0.02 \mathrm{dm})$ consistently occurred within naturally flooded wetlands, regardless of topographic position.

Both upland and waterline zones at ContraCosta had similar VORs of $1.7 \pm 0.2 \mathrm{dm}$ in 2003. During 2004, however, VOR $(2.6 \pm 0.2$ $\mathrm{dm})$ at the waterline position was nearly twice that of uplands $(1.4 \pm 0.2 \mathrm{dm})$, with this pattern reversing in 2005 when uplands $(2.0 \pm 0.2 \mathrm{dm})$ had greater $\operatorname{VOR}(P<0.05)$ than the waterline zone $(0.5 \pm 0.2 \mathrm{dm})$. Moreover, FF wetlands consistently maintained the greatest average VOR across all positions $(2.4 \pm 0.2 \mathrm{dm})$ in each sampling year. With the exception of 2004, when SF wetlands had greater VOR (i.e., similar to that of FF wetlands), no differences existed between the VOR of SF and naturally flooded wetlands from 2003 through 2005, averaging $1.1 \pm 0.2 \mathrm{dm}$. SF wetlands also doubled in VOR between 2003 and 2004, from $1.1 \pm$ $0.2 \mathrm{dm}$ to $2.2 \pm 0.2 \mathrm{dm}$, only to decline by $59 \%$ in 2005 . In contrast, naturally flooded wetlands consistently had low VOR values and did not show any change across sampling years.

At Kitsim, flood regime did not affect VOR at the end-of-flooding treatment period in $2004(P>0.05)$ but did affect VOR during post-reflooding sampling $(P<0.05)$. During 2005 , VOR remained greater in the SF and $1 \mathrm{YNF}$ wetlands than in FF or $2 \mathrm{YNF}$ wetlands (Table 5). Not surprisingly, VOR varied spatially across topographic positions $(P<0.0001)$ at each sampling time, peaking within the wet meadow position and progressively declining with increases in elevation through the dry meadow and upland positions (Table 5). 
TABLE 5. Landscape variation in visual obstruction readings of vegetation in response to 4 flooding treatments ${ }^{\mathrm{a}}$ during end-of-treatment and post-reflooding sampling at Kitsim. Within a sampling period, grand means of flooding treatment or topographic position with different uppercase letters differ $(P<0.05)$. All data are LSmeans.

\begin{tabular}{|c|c|c|c|c|c|c|}
\hline \multirow[b]{2}{*}{ Sampling period } & \multirow[b]{2}{*}{ Topographic position } & \multicolumn{5}{|c|}{ Visual obstruction reading $(\mathrm{dm})$} \\
\hline & & Fall & Spring & $1 Y N F$ & $2 \mathrm{YNF}$ & Mean \\
\hline \multirow[t]{5}{*}{ End of treatment (2004) } & Upland & 0.3 & 1.2 & 0.7 & 0.8 & $0.8 \mathrm{C}$ \\
\hline & Dry Meadow & 1.6 & 1.7 & 1.4 & 1.7 & $1.6 \mathrm{~B}$ \\
\hline & Wet Meadow & 1.9 & 2.2 & 1.5 & 2.6 & $2.0 \mathrm{~A}$ \\
\hline & Mean & 1.3 & 1.7 & 1.2 & 1.7 & \\
\hline & Pooled SE $=0.2$ & & & & & \\
\hline \multirow[t]{5}{*}{ Post-treatment reflooding (2005) } & Upland & 1.0 & 1.5 & 1.6 & 1.2 & $1.3 \mathrm{C}$ \\
\hline & Dry Meadow & 1.9 & 3.3 & 3.7 & 2.4 & $2.8 \mathrm{~B}$ \\
\hline & Wet Meadow & 4.4 & 5.0 & 4.6 & 3.5 & $4.4 \mathrm{~A}$ \\
\hline & Mean & $2.4 \mathrm{~B}$ & $3.2 \mathrm{~A}$ & $3.3 \mathrm{~A}$ & $2.4 \mathrm{~B}$ & \\
\hline & Pooled SE $=0.4$ & & & & & \\
\hline
\end{tabular}

${ }^{\mathrm{a}} \mathrm{FF}=$ fall flooding, $\mathrm{SF}=$ spring flooding, $\mathrm{YYNF}=$ one year no flooding, and $2 \mathrm{YNF}=$ two years no flooding.

\section{Relationship between IBDD and VOR}

At Contra-Costa, there was little relationship between measured VOR sampled within uplands or waterline positions and the breeding density of pintails or other ducks during 2003 ( $P>0.18)$. In 2005, however, after 3 consecutive years of flooding, the IBDD of other ducks had a positive linear relationship with measured VOR on adjacent uplands (Fig. 3). No relationship was found between the density of breeding pintails and measured VOR in the uplands or waterline positions at ContraCosta (e.g., see Fig. 3).

\section{Discussion}

Wetland availability and abundance in spring have been identified as critical factors affecting waterfowl recruitment in the Prairies (Stewart and Kantrud 1973, 1974, Austin and Miller 1995, Koeln et al. 1996). An abundance of ephemeral, temporary, and seasonal wetlands interspersed with short upland vegetation attracts pintails to settle and nest (Stewart and Kantrud 1974, Kaminski and Prince 1984). Results of the present study support this observation but also indicate that, in many years, naturally flooded wetlands with shallow water derived from snowmelt and precipitation may have insufficient water during spring to provide attractive sites for breeding waterfowl, including pintails. Compared to natural wetlands, supplemental flooding in either fall or spring increased the density of pintails and other ducks on newly created wetlands. These results support the notion that wetland quality (i.e., extent of flooding) is an additional determinant of waterfowl use during spring in this region. However, the benefits of recently initiated supplemental FF and SF, such as that seen at Contra-Costa, must also be assessed against the risk associated with creating wetlands in the long-term that contain vegetation less desirable for some species of waterfowl, including pintails (i.e., cattail-dominated wetlands evident at Kitsim). Intermediate flooding strategies to prevent these changes warrant further investigation.

Greater waterfowl abundance in wetlands with supplemental flooding may be related to food availability (Bataille and Baldassarre 1993). Wetlands with more consistent flooding during the breeding season are likely to maintain greater aquatic invertebrate diversity and biomass (Braithwaite and Frith 1969), which is a critical indicator of breeding habitat quality for pintails and other ducks as these food resources provide essential nutrients for egg production (Braithwaite and Frith 1969, Krapu and Reinecke 1992 , Bataille and Baldassarre 1993). Although pintails and other ducks exhibited a similar positive response to supplemental flooding over natural wetlands, both pintails (2005) and other ducks (2004) also demonstrated greater densities under $\mathrm{SF}$ rather than FF in some years. Greater duck densities under SF may occur because this flood regime is more likely to ensure the maintenance of water levels near optimum during the breeding season. For example, FF wetlands are susceptible to variable loss of surface water through ground water infiltration and evaporation, which could reduce water levels below that preferred by waterfowl in spring.

Vegetation is another factor that may account for the observed preference of waterfowl, including pintails, for created wetlands. Wetlands 


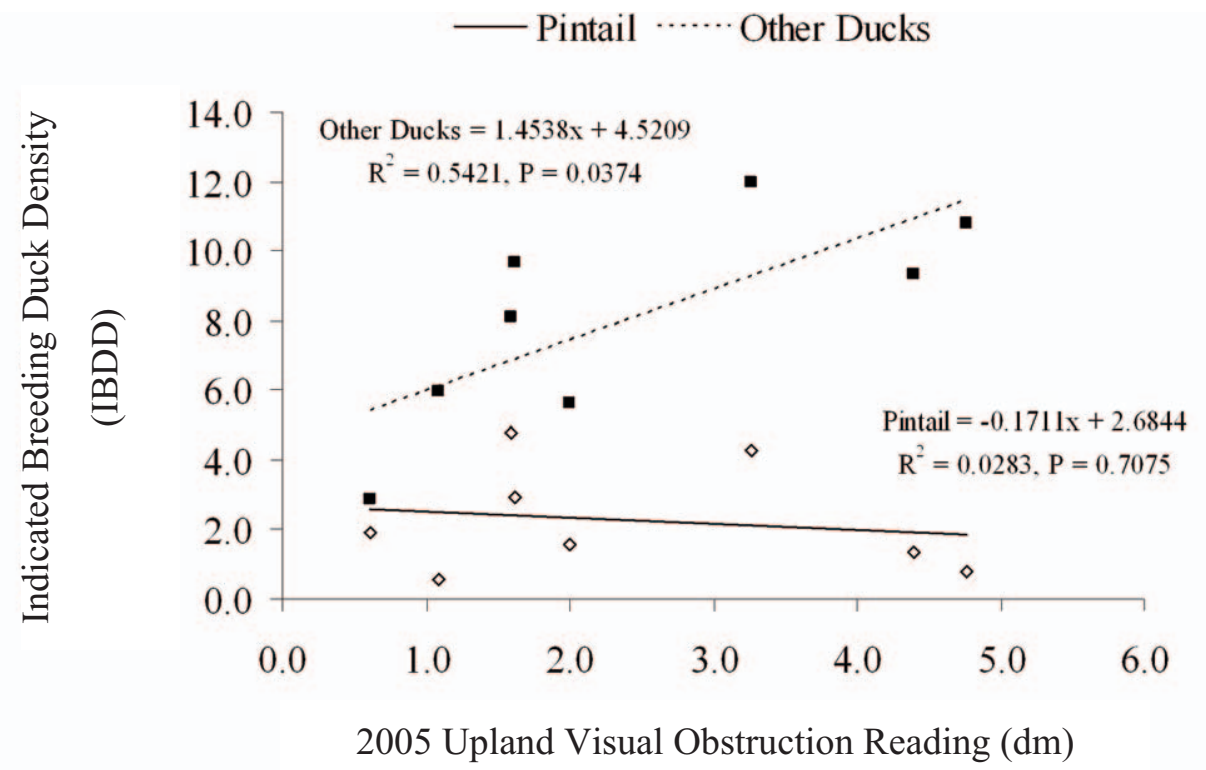

Fig. 3. Relationship of indicated breeding duck density of Northern Pintails and other ducks to upland visual obstruction readings at Contra-Costa during 2005.

receiving supplemental flooding had markedly taller vegetation on and near the shoreline than those with natural flooding, as supported by the VOR assessment. Thus, waterfowl responses to FF and SF may be attributed, at least in part, to the beneficial cover provided by increased vegetation growth. Abundant vegetation at the waterline zone in particular has the benefit of providing foraging habitat and escape cover for many wildlife species, including pintail broods (Duncan 1987). In the current study, other duck abundance responded positively to upland VOR at Contra-Costa, highlighting the potential importance of vegetation density (in addition to moisture availability) as a determinant of breeding waterfowl abundance. Greater upland cover would also enhance breeding habitat for duck species that prefer to nest in uplands adjacent to water bodies. In any case, soil moisture gradients across this Mixedgrass Prairie landscape appeared critical in dictating vegetation density and in subsequently altering habitat conditions within wetlands used by ducks.

Further differences in the abundance of pintails and other ducks between FF and SF wetlands may reflect differences in vegetation composition arising from these treatments. During 2004, FF and SF wetlands at Contra-Costa had similar pintail abundance, likely due to the recent initiation of flooding, leading to similar vegetation structure and visual obstruction at the waterline zone. However, by 2005 , FF wetlands had taller vegetation than SF basins, particularly within subirrigated upland and waterline zones. Previous studies indicate that pintail pairs are attracted to shallow wetlands with low emergent vegetation and low grassland cover on adjacent uplands (Stewart and Kantrud 1973, Kaminski and Weller 1992). Because these conditions were found to a greater extent under SF in the present study, they may account for the greater pintail densities within these wetlands during 2005. Our results are unique in that previous studies (e.g., Robel et al. 1970, Higgins and Baker 1982, Benkobi et al. 2000) did not account for spatial variation in vegetation structure across the landscape, which is associated with seasonal moisture supply.

Unlike pintails, no difference was found in the density of other ducks between FF and SF wetlands during 2005. Other ducks included a number of species with diverse habitat preferences, ranging from small to large wetlands, shallow to deep water, as well as short to tall vegetation structure. This diversity may explain the lack of difference in other duck density between FF and SF wetlands during the final year. Additionally, increased rainfall during 2005 may have reduced hydrologic differences between these treatments (e.g., by augmenting 
FF to create conditions more favorable for a range of duck species).

FF may also have negatively impacted the composition of vegetation in newly created wetlands at Contra-Costa through the maintenance of extended anaerobic conditions in fall and winter, which can be detrimental to certain riparian and aquatic plants (Mitsch and Gosselink 2000). Aquatic plants are known to provide important habitat for the aquatic invertebrates consumed by many species of waterfowl, particularly pintails, during egg production (Krapu 1974, Murkin and Kadlec 1986, Krapu and Reinecke 1992). Decreases in these plants under FF could lead to less suitable habitat for waterfowl. As SF is likely shorter in duration than FF, with subsequent increases in both evaporation and transpiration from growing vegetation, SF may be more likely to maintain desirable vegetation for breeding pintails.

Within established wetlands at Kitsim, the densities both of pintails and other ducks were greatest within wetlands that did not have supplemental flooding for a single year (1YNF) and lowest within wetlands dried for 2 years $(2 \mathrm{YNF})$. The overall low density of pintails and other ducks within $2 \mathrm{YNF}$ wetlands likely reflects the lack of moisture directly associated with cessation of supplemental flooding. This response occurred despite these wetlands remaining at least $25 \%$ flooded (by area) in the spring of each census year as a result of natural recharge from snowmelt and rainfall. This observation was expected because less free-standing water in wetlands renders them less suitable for use by breeding waterfowl (Koeln et al. 1996). Water availability remains the key factor ultimately regulating waterfowl use (Stewart and Kantrud 1974). The limited ability of 2 YNF wetlands to attract ducks following reflooding during the final year of study (2005) suggests that either the depleted water levels from prolonged drying may take more than one year to restore their attractiveness to waterfowl or that the extent of vegetation change within these wetlands may have been detrimental to waterfowl. Notably, reductions in VOR at the dry and wet meadow locations within the $2 \mathrm{YNF}$ treatment extended beyond the drying treatment and into 2005 (i.e., the reflooding period).

In contrast, 1YNF wetlands had greater breeding duck density, including pintails, than all other treated wetlands at Kitsim. This response may reflect more desirable habitat conditions for ducks associated with a combination of (1) a moderate reduction in water to levels nearer the optimum and (2) an associated change in vegetation to conditions preferred by pintails. Short-term drying would allow moisture to decline to levels that may favor either invertebrate production (Frederickson and Heitmeyer 1991, Batzer 2004) or foraging efficiency by waterfowl (Safran et al. 1997). Greater invertebrate abundance has been linked to improved nutrient availability following reflooding of prairie wetlands (Murkin and Ross 2000). Similarly, changes in vegetation structure within the $1 \mathrm{YNF}$ treatment may explain the greater total density of breeding ducks in these wetlands. Short-term drying of wetlands at Kitsim created shorter vegetation, potentially favoring waterfowl such as pintails.

Overall, our results reinforce the notion that Northern Pintails prefer ephemeral, temporary, and seasonal wetlands with moderate flooding, where vegetation changes are limited in nature (Stewart and Kantrud 1973, Kaminski and Weller 1992). These results suggest that shortterm drying (i.e., periodic flood cessation) may improve the attractiveness of older wetlands to ducks. Moreover, this explanation accounts for why pintails generally comprised a relatively small fraction of the total waterfowl $(4.4 \%$ $8.8 \%$ ) within established wetlands at Kitsim compared to waterfowl at newly established wetlands at Contra-Costa $(13.5 \%-18.8 \%)$. Unlike wetlands at Contra-Costa, Kitsim wetlands were dominated by extensive stands of cattail at the beginning of the study, conditions considered less attractive to pintails.

There was also pronounced temporal variation in the breeding density of pintails at Kitsim. Breeding pintail density declined sharply from 2003 to 2004 , and subsequently increased in 2005 across the area. Fluctuations in wetland flooding can affect breeding waterfowl abundance (Stewart and Kantrud 1974) and food availability (Braithwaite and Frith 1969, Frederickson and Heitmeyer 1991) in the prairies. Such fluctuations are less likely to be a factor here, as pintail densities declined markedly on all treatments, including areas with sustained annual flooding (i.e., fall and spring wetlands). Instead, factors other than water availability appear to have affected pintail densities throughout the 3 years of the study across the Kitsim area, and these factors remain unaccounted for. Conversely, pintails may assess wetland 
conditions on a broader scale than represented by our study sites. Such assessment could influence settling patterns at smaller or more-local scales.

Finally, the size of newly initiated wetlands appeared to have little relation with pintail breeding density in the region. These results are unlike those for other areas of the Northern Great Plains (Stewart and Kantrud 1974), where pintails show a strong affinity for wetlands of $<5$ ha. Small wetlands are typically shallower, more productive, and interspersed with the short-structured vegetation preferred by pintails (Kaminski and Prince 1984, Kaminski and Weller 1992). In contrast, other ducks appeared to favor larger wetlands at Contra-Costa, at least shortly after supplemental flooding began. Because "other ducks" includes diving ducks, an observed preference of other ducks for larger water bodies with deeper water may be expected.

\section{Management Implications}

Supplemental flooding was an effective means of enhancing densities of breeding pintails and other duck species in existing and created wetlands of the Dry Mixedgrass Prairie. Thus, conservation programs that create new or enhanced wetlands in the region are likely to benefit local duck populations. Duck densities were also greater within newly created wetlands flooded during spring rather than fall, although this increase was limited to 1 in 3 years. These findings suggest that $\mathrm{SF}$, which approximates the natural moisture recharge processes and maintains habitat conditions (i.e., shorter vegetation) closer to the historical norm, may be more beneficial for creating wetlands preferred by waterfowl. Nevertheless, our results indicate that FF also remains significantly beneficial and may remain necessary for pragmatic reasons in the Eastern Irrigation District because of greater water availability in the fall.

Modification of flooding regimes within established wetlands indicated that 2 years of flood cessation was detrimental to duck abundance. In contrast, short-term flood cessation for one year increased the abundance of both pintails and other ducks, even compared to the historical practice of annual FF. Short-term wetland drying appeared to provide an optimal balance between changes in wetland hydrology favoring the development of shorter vegetation and maintenance of open water needed by waterfowl during breeding. Additionally, pintail densities within established wetlands generally remained lower than densities observed in newly created wetlands, suggesting that flooding should be carefully planned to optimize the ongoing use of wetlands by Northern Pintails and other ducks.

\section{ACKNOWLEDGMENTS}

This research was supported by the University of Alberta and a grant from Ducks Unlimited Canada (DUC). Special thanks to DUC for establishing and maintaining the managed wetlands evaluated in this study, to Dave Kay and Morgan Stromsmoe of DUC for providing the original impetus for this research, and to DUC field staff from the Brooks office in southern Alberta, namely Stacey Wabick, Nathan Fontaine, and Brian Peers, who assisted with various technical aspects of the study. We also thank Dr. Laki Goonewardene for advice on the statistical analysis and Drs. Lee Foote, Anne Naeth, Robert Hudson, and Jeff Mosley for providing helpful comments on an earlier version of the manuscript.

\section{Literature Cited}

AsAmOAH, S.A. 2008. Vegetation, livestock and waterfowl responses to hydrologic gradients in created wetlands of the Dry Mixedgrass Prairie. Doctoral dissertation, University of Alberta, Edmonton, Alberta. $333 \mathrm{pp}$.

Austin, J.E., And M.R. Miller. 1995. Northern Pintails (Anas acuta). No. 163 in A. Poole and F. Gill, editors, The birds of North America. Academy of Natural Sciences, Philadelphia, PA, and American Ornithologists' Union, Washington, DC.

Bataille, E.J., AND G.A. BALDassarRe. 1993. Distribution and abundance of aquatic macroinvertebrates following drought in three prairie pothole wetlands. Wetlands 13:260-269.

BATZER, D.P. 2004. Movements of upland invertebrates into drying seasonal woodland ponds in northern Minnesota, USA. Wetlands 24:704-907.

Benkobi, L., D.W. Uresk, G. Schenbeck, and R.M. King. 2000. Protocol for monitoring standing crop in grassland using visual obstruction. Journal of Range Management 53:627-633.

BoyD, H. 1985. The large-scale impact of agriculture on ducks in the Prairie Provinces, 1950-81. Canadian Wildlife Service Program Notes 149. 13 pp.

Braithwaite, L.W., and H.J. Frith. 1969. Waterfowl in an inland swamp in New South Wales. III. Breeding. CSIRO Wildlife Research 14:65-109.

DunCAN, D.C. 1987. Nest-site distribution and overland brood movement of Northern Pintails in Alberta. Journal of Wildlife Management 51:716-723.

Dzubin, A. 1969. Assessing breeding populations of ducks by ground counts. Saskatoon Wetlands Seminar. Canadian Wildlife Service Report Series - No. 6:178-237. 
Frederickson, L.H., And M.E. Heitmeyer. 1991. Life history strategies and habitat needs of the Northern Pintail. In: Waterfowl management handbook. Fish and Wildlife Leaflet 13, U.S. Fish and Wildlife Service, Washington, DC.

HigGins, K.F., AND W.T. BAKER. 1982. Changes in vegetation structure in seeded nesting cover in the Prairie Pothole Region. Special Scientific Report - Wildlife No. 242, U.S. Fish and Wildlife Service.

Kaminski, R.M., AND H.H. PRInCE. 1984. Dabbling duckhabitat associations during spring in Delta Marsh, Manitoba. Journal of Wildlife Management 48:37-50.

KAMINSKI, R.M., AND M.W. WELLER. 1992. Breeding habitats of Nearctic waterfowl. Pages 568-589 in B.D.J. Batt, A.D. Afton, M.G. Anderson, C.D. Ankney, D.H. Johnson, J.A. Kadlec and G.L. Krapu, editors, Ecology and management of breeding waterfowl. University of Minnesota Press, Minneapolis, MN.

KEITH, L.B. 1961. A study of waterfowl ecology on small impoundments in southeastern Alberta. Wildlife Monograph 6:1-87.

Koeln, G.T., L.M. Cowardin, and L.L. Strong. 1996. Geographic Information Systems. In: T.A. Bookhout, editor, Research and management techniques for wildlife and habitats. 5th edition. The Wildlife Society, Bethesda, MD. 740 pp.

KRAPU, G.L. 1974. Feeding ecology of pintail hens during reproduction. Auk 91:278-290. 2000. Temporal flexibility of reproduction in temperate-breeding dabbling ducks. Auk 117:640-650.

Krapu, G.L., AND K.J. ReInECKE. 1992. Foraging ecology and nutrition. Pages 1-29 in B.D.J. Batt, A.D. Afton, M.G. Anderson, C.D. Ankney, D.H. Johnson, J.A. Kadlec and G.L. Krapu, editors, Ecology and management of breeding waterfowl. University of Minnesota Press, Minneapolis, MN.

Millar, J.B. 1989. Perspectives on the status of Canadian prairie wetlands. In: R.R. Sharitz and J.W. Gibbons, editors, Freshwater wetlands and wildlife. U.S. Department of Energy, Rep. DE 9000584, National Technical Information Service, Springfield, VA.

Miller, M.R., AND D.C. DunCan. 1999. The Northern Pintail in North America: status and conservation needs of a struggling population. Wildlife Society Bulletin 27:788-800.

Mitsch, W.J., AND J.G. Gosselink. 2000. Wetlands. Wiley \& Sons, New York, NY. $920 \mathrm{pp}$.

Murkin, H.R., and J.A. KadLEC. 1986. Responses of benthic macroinvertebrates to prolonged flooding of marsh habitat. Canadian Journal of Zoology 64:65-72.

Murkin, H.R., AND L.C.M. Ross. 2000. Invertebrates in prairie wetlands. In: H.R. Murkin, A.G. van der Valk, and W.R. Clark, editors, Prairie wetland ecology: the contributions of the Marsh Ecology Research Program. Iowa State University Press, Ames, IA.

[NAWMP] North American Waterfowl Management Plan Committee. 2004. North American Waterfowl
Management Plan 2004. Strategic Guidance: Strengthening the Biological Foundation. Canadian Wildlife Service, U.S. Fish and Wildlife Service, and Secretaría de Medio Ambiente y Recursos Naturales. 22 pp.

NudDs, T.D., AND R.G. ClaRK. 1993. Landscape ecology, adaptive resource management, and the North American Waterfowl Management Plan. In: G.L. Holroyd, H.L. Dickson, M. Regnier, and H.C. Smith, editors, Proceedings of the 3rd Prairie Conference and Endangered Species Workshop. Provincial Museum of Alberta Natural History Occasional Paper 19.

Podruzny, K.M., J.H. DeVries, L.M. Armstrong, and J.J. RotelLA. 2002. Long-term response of Northern Pintails to changes in wetlands and agriculture in the Canadian Prairie Pothole Region. Journal of Wildlife Management 66:993-1010.

Robel, R.J., J.N. Briggs, A.D. Dayton, and L.C. Hulbert. 1970. Relationships between visual obstruction measurements and weight of grassland vegetation. Journal of Range Management 23:295-297.

SAFran, R.J., C.R. Isola, M.A. Colwell, AND O.E. WILLIAMS. 1997. Benthic invertebrates at foraging locations of nine waterbird species in managed wetlands of the northern San Joaquin Valley, California. Wetlands 17:407-415.

SAVARD, J.P.L., W.S. Boyd, AND G.E.J. SMith. 1994. Waterfowl-wetland relationships in the Aspen Parkland of British Columbia: comparison of analytical methods. Hydrobiologia 279/280:309-325.

SAnkowski, T.P., K.L. Schmitt, S.J. Guinn, G.R. Stewart, R.B. Burns. 1987. The Kitsim Complex, an example of a small wetland development benefitting waterfowl and cattle production. Pages 189-193 in C.D.A. Rubec and R.P. Overend, editors, Proceedings: Symposium '87 Wetlands-Peatlands, 23-27 August 1987. Environment Canada, Edmonton, Alberta, Canada.

SAS InstituTE, InC. 2003. SAS user's guide. Version 9.1. SAS Institute, Inc., Cary, NC.

Steele, R.G.D., T.H. Torrie, and D.A. Dickey. 1997. Principles and procedures of statistics: a biometrical approach. 3rd edition. McGraw-Hill Series in Probability and Statistics. McGraw-Hill, New York, NY.

StEWART, R.E., AND H.A. KantRud. 1973. Ecological distribution of breeding waterfowl populations in North Dakota. Journal of Wildlife Management 37:39-50.

1974. Breeding waterfowl populations in the Prairie Pothole Regions of North Dakota. Condor 76:70-79.

[USFWS] United States Fish and Wildlife Service. 1987. Standard operating procedures for aerial waterfowl breeding ground population and habitat surveys in North America. Unpublished report.

Received 11 August 2010 Accepted 20 May 2011 